\title{
Thomas Jefferson e o problema da escravidão
}

\author{
WILLIAM COHEN
}

$\mathrm{P}$ ARECE PARAdOXAL que Thomas Jefferson, um dos eternos heróis da democracia norte-americana, fosse também o proprietário de mais de 180 escravos exatamente à época em que proclamava que todos os homens foram criados iguais e foram "dotados por seu Criador" com os "direitos inalienáveis" à "vida, liberdade e à busca da felicidade". Além disso, ao longo da existência ele continuou afirmando que a escravidão era injusta e imoral. Em 1785 usara a frase "avareza e opressão" para caracterizar o interesse escravista e a contrastara com o "direito sagrado" à emancipação. Um ano depois, admirava-se ao constatar que patrio-

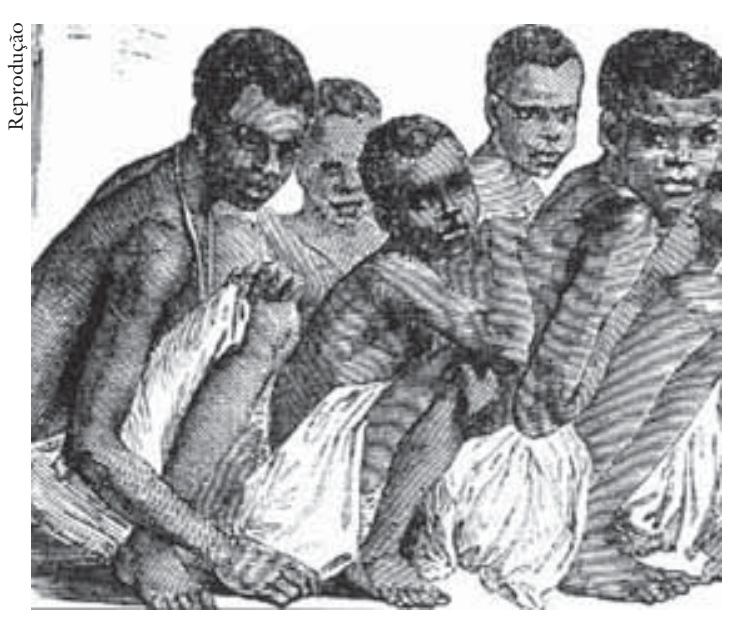

A posição em que os escravos dormiam tas norte-americanos que haviam suportado castigos físicos, fome e prisão nas mãos de seus opressores britânicos pudessem infligir "em seus semelhantes um cativeiro uma hora do qual produz mais infelicidade do que séculos daquele cativeiro contra o qual se insurgiram e combateram". No último ano de vida, Jefferson reiterou sua crença de que era ilegal "um homem apropriar-se para seu uso das faculdades de outro sem seu consentimento" (1).

A maiora dos estudiosos de Jefferson tratou dessa contradição ou ignorando-a ou citando seus pontos de vista sobre a abolição e sustentando que seu papel como proprietário de escravos foi uma herança que lhe coube. Nascido num sistema escravista, argumentam, não poderia ele em sã consciência abandonar seus dependentes negros; fez o melhor que pôde nessa situação ruim, comportando-se como um senhor benevolente e compreensivo. De fato, o biógrafo mais competente e que mais a fundo pesquisoulhe a vida afirma: "se o próprio senhor errou [no tratamento dispensado a seus escravos] ele o fez do lado da brandura” (2). 
Essa argumentação encontra apoio nas próprias observações de Jefferson. O mais conhecido de seus comentários é a resposta a uma carta de Edward Coles, um senhor de escravos da Virgínia, que, em 1814, insistia para que ele tomasse a liderança na causa da abolição e descrevia seu próprio plano de mudar-se para um estado livre. Jefferson respondeu concordando com os sentimentos de Coles e dizendo: "O amor à justiça e o amor ao país pleiteiam igualmente a causa do povo [escravo], e é para nós uma vergonha moral que eles a tenham pleiteado em vão por tão largo tempo, sem que isso produzisse um único esforço, nem, receio, bem pouca vontade séria de aliviá-los a eles e a nós mesmos de nossa condição, moral e politicamente condenável” (3).

Jefferson descrevia em seguida sua própria idéia de um plano prático para a abolição, mas atentando para o fato de que ele era agora um velho, deixava o empreendimento antiescravista para os jovens "que podem leválo a bom termo". Insistia para que Coles não fugisse à sua responsabilidade com relação a seus escravos deixando a Virgínia e acrescentava: "até que mais se possa fazer por eles, devemos lutar ao lado dos que a sorte pôs em nossas mãos, para alimentá-los e vesti-los bem, protegê-los contra todos os maus tratos, exigir deles apenas o trabalho razoável que é realizado voluntariamente pelos homens livres, não permitindo que qualquer sentimento de repugnância nos leve a abdicar deles e de nossos deveres para com eles" (4).

Essa visão de Jefferson como senhor proto-abolicionista começou a sofrer ataques em 1961. Robert McColley, em Slavery and Jeffersonian Virginia, retratou o autor da Declaração da Independência como alguém que acreditava na inferioridade dos negros e cujas ações públicas muitas vezes favoreciam o sistema escravista. Visando a demostrar que a instituição da escravidão de fato se tornou mais forte durante a época pós-revolucionária, essa obra muitas vezes usou Jefferson como exemplo da classe dos senhores de plantations e argumentou que o interesse político e a ideologia racista o impediram de trabalhar efetivamente contra o sistema (5).

Mais recentemente, Winthrop Jordan dedicou um capítulo de seu estudo à análise da contradição no pensamento de Jefferson sobre o tema da servidão negra. Aceitando a formulação tradicional de que o virginiano fora vítima de um sistema que aborrecia, Jordan definiu o dilema central de Jefferson como o fato de que ele "odiava a escravidão mas julgava os negros inferiores aos brancos". Observando o envolvimento pessoal de Jefferson com o sistema escravista, Jordan concluiu que "seu ódio sincero à escravidão não provinha tanto desse molesto enredamento pessoal com o dia-adia dos escravos quanto do sistema de política em que estava mentalmente preso" (6). 
Jordan tratou o problema quase exclusivamente em termos das idéias e emoções de Jefferson, e sua análise perspicaz descreveu a confusão que resultou do choque de tendências contraditórias no pensamento do virginiano. Primeiro, sua crença numa criação única e num universo regido pela lei natural o levou inexoravelmente para a visão de direitos naturais aplicados aos negros pelo fato de que eles também são seres humanos. Segundo, Jefferson também alimentava uma crença intuitiva na inferioridade dos negros, que tentava encobrir com um apelo à ciência, mas que na verdade se originava da interação de sua constituição psicológica e dos mores da sociedade que o rodeava. Sua recusa de aceitar uma explicação ambientalista para a aparente inferioridade dos negros o levou à confusão que Jordan chamou de "monumental". Pois se os negros eram por natureza inferiores, então Jefferson deve ter suspeitado que pudesse o Criador de fato tê-los criado desiguais; mas isso ele não poderia dizer sem conferir à sua asserção exatamente a mesma força lógica de sua famosa declaração em sentido contrário" (7).

O trabalho de Jordan é válido por sua análise da confusão intelectual de Jefferson com relação à escravidão, mas não investiga seu relacionamento quotidiano com o sistema escravista. Esse relacionamento é importante porque o envolvimento prático com o sistema da servidão negra indica que, enquanto suas crenças racistas eram em geral congruentes com suas ações, os pontos de vista libertários sobre esse sistema tendiam a ser meras abstrações intelectuais. Isso se aplica especialmente aos anos depois de 1785; e num grau menor também vale para o período anterior.

Quando da morte de seu pai em 1757, Jefferson herdou mais de cinco mil acres de terra e 20 escravos. Pelo ano de 1774 o crescimento natural, compras e a transferência por escritura de todos os negros de propriedade de sua mulher fizeram o número subir para 42. Nessa época ele adquiriu (em nome de sua mulher) outros 11 mil acres e 135 escravos como parte que lhe coube do patrimônio de seu sogro, John Wayles. Dívidas que gravavam essa propriedade motivaram a venda de aproximadamente a metade do novo terreno. Mas mesmo assim restaram-lhe mais de cinco mil acres que, somados às suas terras, lhe davam uma propriedade de mais de dez mil acres, patrimônio que mais ou menos se manteve igual até sua morte (8).

Como conseqüência da herança, Jefferson possuía 187 homens, mulheres e crianças, mas o número mudava a cada ano com novos nascimentos, mortes, compras e vendas. Em 1783, apesar de ele perder 30 escravos para os ingleses, o total subiu para 204. Em 1798, possuía apenas 147 negros porque vendera mais de 50 para saldar dívidas. O número subiu para 197 em 1810; e, pelo ano de 1822, atingiu 267. Depois de 1774, as proprie- 
dades em terras e negros faziam de Jefferson o segundo cidadão mais rico no condado de Albermale e um dos mais ricos da Virgínia (9).

Sua nova posição não lhe impediu a defesa da abolição do tráfico de escravos e da própria escravidão durante os anos de 1774-1784, mas não se deve exagerar a extensão de tal atividade. Em 1774, à medida que aumentava sua oposição aos britânicos, Jefferson acusou o monarca da Inglaterra de rejeitar as leis da Virgínia que teriam posto um fim ao tráfico de escravos na colônia. Pondo a culpa no governo britânico sem condenar os que na época perpetuavam o sistema, afirmava: "Pelas razões mais fúteis, ... sua majestade rejeitou leis da tendência mais salutar. A abolição da escravidão doméstica é o grande objetivo desejado destas colônias onde ela foi infelizmente introduzida no estágio inicial delas. Mas antes de libertar os escravos que possuímos, é necessário excluir quaisquer outras importações da África. Todavia, nossas repetidas tentativas de efetuar essa tarefa ... foram até agora derrotadas pela negativa de sua majestade (10).

Com o agravamento da crise com a Inglaterra, Jefferson tornou-se mais positivo em sua oposição ao tráfico de escravos. Sua versão de 1776 de uma constituição para a Virgínia continha uma cláusula segundo a qual "Nenhuma pessoa que após esta data chegue a este país [a Virgínia] será mantido em escravidão sob qualquer pretexto que seja" (11). O documento não foi adotado, mas Jefferson continuou a atacar o tráfico de escravos; e em sua versão da Declaração da Independência incluiu um parágrafo que faz lembrar as observações que fizera em 1774. George III, acusava: "promoveu uma guerra cruel contra a própria natureza humana, violando seus direitos mais sagrados à vida e liberdade nas pessoas de um povo distante que nunca o ofenderam. ... Essa guerra de piratas, o opróbrio de poderes infiéis, é a guerra do rei cristão da Grã-Bretanha. Determinado a manter aberto um mercado em que se compram e se vendem homens, ele prostituiu seu veto pela supressão de todas as tentativas de proibir ou restringir esse execrável comércio ... (12).

Jefferfson desferiu esse ataque apesar do fato de que sua fortuna se baseava em lucros obtidos com o tráfico de escravos. Seu sogro exercera essa atividade, e vários dos cativos herdados por Jefferson tinham nomes africanos. Além disso, as localizações dos alojamentos dos negros apareciam em seu Farm book sob apelativos tais como Angola e Guiné (13).

Muito mais significativa, porém, foi a acusação de Jefferson de que o tráfico de escravos violava os "direitos mais sagrados à vida e liberdade nas pessoas de um povo distante". Tais palavras mostram claramente que, quando falava de "direitos inalienáveis" do homem, ele se referia também aos ne- 
gros. Isto não significa que ele acreditasse terem as raças dotes iguais. Em 1784, expressou a "suspeita" de que os negros eram inerentemente inferiores aos brancos. E parece que manteve esse ponto de vista por toda a vida. A aparente contradição entre sua crença em direitos iguais e sua posição de que os negros não estavam em pé de igualdade com os brancos tem uma explicação parcial em observações feitas em 1809, quando argumentava: "qualquer que fosse seu grau de talento, tal grau não constituía a medida de seus direitos. O fato de Sir Isaac Newton ser superior aos outros em entendimento não o tornava senhor de algumas pessoas ou propriedade de outras" (14).

Em 1778 a Virgínia proscreveu o tráfico de escravos. Não há provas de que Jefferson tenha participado diretamente para garantir a aprovação dessa lei, mas não se pode duvidar de que, no mínimo, ele ajudou a preparar o clima para a sua aprovação (15). Contudo, a lei não levou às emancipações que segundo Jefferson viriam em sua esteira. De fato, não havia necessariamente qualquer conexão entre a oposição ao tráfico de escravos e o apoio à própria escravidão. No caso de Jefferson, é muito provável que houvesse uma ligação entre sua oposição a esse comércio e a aversão pela escravidão, mas outros senhores talvez se opusessem por uma gama variada de razões incluindo-se a percepção de que o preço dos escravos subiria se o tráfico fosse interrompido.

Jefferson era mais cuidadoso quando lidava com a questão da abolição. Em 1769, durante seu primeiro mandato na House of Burgesses, apoiou a proposta a favor de uma lei que permitiria que os senhores alforriassem seus escravos, mas ela não passou. Quando tal lei foi adotada em 1782, Jefferson não libertou seus cativos (16). Em outras três ocasiões propôs planos específicos que pediam a emancipação, mas não foi tão incisivo na insistência por sua adoção e apenas o Regulamento de 1784 foi de fato exposto à consideração de um organismo público (17).

Em novembro de 1776 Jefferson foi escolhido como membro de uma comissão cuja tarefa era revisar, modernizar e codificar os estatutos da Virgínia. Entre suas atribuições estava o trabalho de redigir uma legislação que tratasse dos escravos. Mais tarde ele descreveu tal projeto de lei, que concluiu em 1778, como uma "mera compilação" da legislação existente sobre o assunto, e até certo ponto era verdade. O projeto continha uma versão reforçada de uma lei que proibia o tráfico de escravos, e Jefferson estava simplesmente codificando leis anteriores quando incluiu cláusulas impedindo que negros testemunhassem contra brancos e proibindo escravos de ter armas ou de deixar a propriedade de seus senhores sem autorização. As medidas de Jefferson também incluíam a costumeira pena do chico- 
te para o escravo que cometesse ofensas como desordem, discursos subversivos e fuga. Mas também neste ponto ele estava copiando legislação anterior (18).

Apesar de tudo, o projeto de lei era mais do que uma compilação de códigos anteriores e continha algumas adições significativas que visavam a impedir o crescimento da população de negros livres no estado. Tornava-se ilegal para negros livres ingressar na Virgínia por vontade própria ou lá permanecer por mais de um ano depois de sua emancipação. Uma mulher branca que tivesse um filho negro teria a obrigação de deixar o estado dentro de um ano. O indivíduo que violasse essa legislação se situaria "fora da proteção das leis" (19). Tal falta de proteção os sujeitava à reescravização ou até mesmo à morte por simples caprichos de vizinhos e, assim, constituía uma punição severíssima.

Argumentou-se que Jefferson teria incluído essas cláusulas acreditando que a escravidão se extinguiria aos poucos pela ausência de novos recrutas para reabastecer a estirpe. Esse pode ter sido o motivo, mas parece improvável em vista de seu conhecimento da proporção de nascimentos com relação aos óbitos em sua plantation. Durante os anos de 1774-1778 houve no mínimo 22 nascimentos e 12 óbitos entre seus negros (20). Deve ter ficado óbvio então que impedir outras importações e limitar o crescimento da população de negros livres não deteria o aumento da população de escravos por causas naturais. Outra explicação, essa mais razoável, refere-se a preocupação de Jefferson quanto a uma população bastante grande de negros livres constituir um eventual estímulo a rebeliões entre os escravos.

Em 1784 Jefferson redigiu sua emenda à Lei Referente aos Escravos. Por ela seriam libertados todos os cativos nascidos depois de sua aprovação. De maneira significativa, a emenda também estabelecia que depois de um período de educação adequado esses negros "deveriam ser levados para viver numa colônia em local que as circunstâncias da época tornassem mais apropriado", pois Jefferson não conseguia imaginar as duas raças convivendo em paz em pé de igualdade. Quando em 1785 o projeto de lei foi para o legislativo para a aprovação final, a emenda não foi incluída porque o virginiano "pensou que a opinião pública ainda não suportaria o projeto". Ele deve ter tido sérias dúvidas o tempo todo sobre sua aceitabilidade. Não há provas independentes (fora da própria declaração de Jefferson) da existência delas, e ele nada fez para ajudar a criar uma recepção favorável para a sua proposta de revisão (21). Além disso, o emprego das palavras “em local que as circunstâncias da época tornassem mais apropriado" parece sugerir que ele não acreditava realmente que sua sugestão seria adotada num futuro imediato. 
O mais importante ato legislativo isolado na carreira de Jefferson foi a redação de uma cláusula para o Regulamento de 1784, que teria proibido a escravidão no território do Oeste (Norte e Sul) depois de 1800 (22). Nessa proposta está o germe da doutrina do solo livre do século XIX, que aceitava a existência da escravidão onde já estivesse estabelecida e tentava deter sua expansão em novas áreas. Como muitos de seus sucessores na teoria do solo livre, Jefferson buscava proteger os brancos dos efeitos nocivos da escravidão; e certamente não acreditava que os negros pudessem, ou devessem, tornar-se parceiros iguais na construção dessas novas comunidades do Oeste. $\mathrm{O}$ conjunto de seus escritos mostra que ele nunca considerou seriamente a possibilidade de alguma forma de coexistência racial em pé de igualdade e que, pelo menos de 1778 até sua morte, via a colonização como a única alternativa para a escravidão (23).

A proposta de Jefferson sem dúvida prenunciava esses aspectos da doutrina do solo livre, mas dificilmente se pode atribuir a ele o crédito da autoria da parte da doutrina segundo a qual, se fossem barradas futuras expansões da escravidão, ela se extinguiria naturalmente. Se tais pensamentos estavam em sua cabeça em 1784, ele com certeza os havia repudiado em 1820. E quando a questão do Missouri dividiu a nação, Jefferson escreveu: "De uma coisa tenho certeza, de que o deslocamento de escravos de um estado para outro não transforma em escravo nenhum ser humano que já não o seja sem tal deslocamento; assim a dispersão deles por uma superfície mais ampla os faria individualmente mais felizes e na mesma proporção facilitaria sua emancipação dividindo o peso por um número maior de colaboradores” (24).

O Regulamento de 1784 não conseguiu a aprovação por um voto, mas mesmo que se tivesse transformado em lei, o cativeiro teria continuado legal na área por 16 anos. E parece provável que, se se permitisse que a instituição da escravidão tomasse pé no território, sua proibição teria sido rejeitada. Mesmo depois que o Regulamento de 1787 baniu a escravidão do território do Noroeste, havia um sentimento muito difundido a favor da rescisão da cláusula de exclusão, e em 1802 realizou-se uma convenção em Indiana sob os auspícios do governador William Henry Harrison para pedir que o Congresso a revogasse. $\mathrm{O}$ pedido foi negado mas, se se houvesse concedido um período de 16 anos de tolerância da escravidão em todo o território, talvez o Congresso tivesse sido forçado a ceder (25). Assim, o Regulamento do Noroeste de 1787 diferiu significativamente da proposta de Jefferson porque, ao estabelecer liberdade imediata para a região, fez com que a possibilidade de uma rejeição ulterior se tornasse menos provável. O Regulamento de 1784 assinalou a sua última tentativa pública de limitar e terminar a escravidão. Depois disso, a oposição restringiu-se a car- 
tas pessoais endereçadas a homens cujas opiniões pareciam concordar com ele nos pontos principais. Em tais comunicações ele lamentava a escravidão e defendia a expatriação como solução única para esse difícil problema (26).

Um ponto que emerge com grande clareza numa avaliação da carreira antiescravista de Jefferson refere-se à sua firme oposição ao tráfico de escravos. Nesse assunto, contando com o apoio da opinião pública, ele não transigiu nem assumiu uma posição moderada.

No todo, porém, havia uma distância significativa entre o seu pensamento e a ação acerca da questão abolicionista. Não tinha dúvida alguma de que era moral e politicamente ruim manter um outro ser humano na escravidão, mas continuava a fazê-lo. Acreditando que o cativeiro deveria ser abolido, escreveu uma emenda que teria realizado a abolição de modo gradativo. Mas a manteve em segredo temendo que a opinião pública não estivesse preparada. Enquanto isso, codificou a lei sobre os escravos da Virgínia e acrescentou-lhe cláusulas duras que iam contra os negros livres. Concordava com a conveniência de manter a escravidão fora dos territórios do Oeste, mas sua proposta teria permitido que o mal se mantivesse em incubação por um período de 16 anos.

A contradição na posição intelectual de Jefferson resultou em grande parte de sua atitude equivocada com relação à questão da igualdade racial (27). A única explicação sistemática de sua maneira de ver o conceito de raça encontra-se em Notes on the State of Virginia [Notas sobre o Estado da Virgínia]. Mesmo aqui, a ambigüidade de sua posição é revelada por suas tentativas de impedir que o trabalho se tornasse público, receando que os termos empregados para falar da escravidão e da constituição da Virgínia pudessem "produzir uma irritação capaz de virar as cabeças de nossos compatriotas contra a reforma contida nos dois artigos e assim causar mais dano que benefício" (28). Além disso, Jefferson deve ter percebido que tais afirmações poderiam prejudicar sua carreira política provocando a ira dos concidadãos sulistas.

Apesar da tentativa de impedir a publicação do livro, suas observações em geral eram moderadas. Na discussão da "revisão" das leis da Virgínia, descrevia sua emenda propondo "emancipar todos os escravos nascidos após aprovação do projeto" e em seguida explicava por que a alforria coletiva deveria vir acompanhada da expatriação dos negros libertos. Seria impossível "reter e incorporar os negros no estado", argumentava ele, porque o preconceito dos brancos e a memória dos negros com relação a injustiças passadas levariam a desordens (29). Jefferson também discutiu as barreiras físicas e morais que em sua opinião não permitiriam a convivência harmoniosa das duas raças em liberdade. 
Fez uma série de observações sobre as diferenças físicas e comportamentais entre as duas raças, sugerindo que os negros eram mais rudes e animalescos que os brancos. Via maior beleza nos cabelos soltos e nos variados tons de pele dos caucasianos do que na "imóvel máscara escura" que encobria as emoções dos negros, e notava que eles mesmos pareciam preferir os brancos. Uma vez que o fator da beleza superior merecia atenção na procriação de animais domésticos, perguntava ele, "por que não na do homem". Observava que os negros suam mais e urinam menos que os brancos, o que faz que eles tenham um "odor mais forte e desagradável”. Parecia-lhe que eles precisam de menos tempo de sono e que suas mágoas são "simplesmente passageiras". Além disso, eles eram "mais ardentes em sua busca da fềmea; mas parece que para eles o amor é mais uma questão de desejo do que uma delicada mistura de sentimento e sensação" (30).

Jefferson descobriu que os negros são iguais aos brancos quanto à memória, mas são muito inferiores na capacidade de raciocínio. Em imaginação eles eram "insensíveis, desprovidos de bom gosto e anômalos". Via pouco o que elogiar à luz de padrões objetivos nos trabalhos de escritores negros que lhe chamaram a atenção. Referindo-se à poetisa negra, Phillis Wheatley, elogiou o efeito da religião sobre seus sentimentos, mas acreditava que suas composições estavam "abaixo da dignidade da crítica" (31). Em 1791, Jefferson expressou grande respeito pelas elegantes soluções simétricas de Benjamin Banneker, um matemático negro. Todavia, em 1809, ver-balizava a suspeita de que Banneker teria conseguido suas realizações com a assistência de brancos. Prosseguiu afirmando que uma carta do matemático mostrava "uma inteligência de estatura de fato muito comum" (32).

Em Notes on the State of Virginia, e também em outros escritos, as observações de Jefferson geralmente foram feitas nos tons imparciais do investigador científico. Tendo nítida consciência do argumento ambientalista, sinceramente expressava o desejo de que futuras provas pudessem demonstrar que a inferioridade dos negros dependia de sua condição e não da natureza (33). Contudo, não parecia alimentar grandes esperanças de que esse fosse o caso; e seu apelo à ciência talvez tenha sido, como enfatizou Jordan, um verniz que encobria a conclusão já formada de que "não foi sua condição, portanto, mas sim a natureza que produziu a distinção" entre as realizações intelectuais de negros e brancos (34). Mas, no fim, contentou-se com uma declaração conjectural: "Proponho, portanto, apenas como suspeita, que os negros, quer formem uma raça distinta desde a origem, quer tenham se tornado distintos pela ação do tempo e suas circunstâncias, são inferiores aos brancos em seus dotes físicos e mentais" (35). 


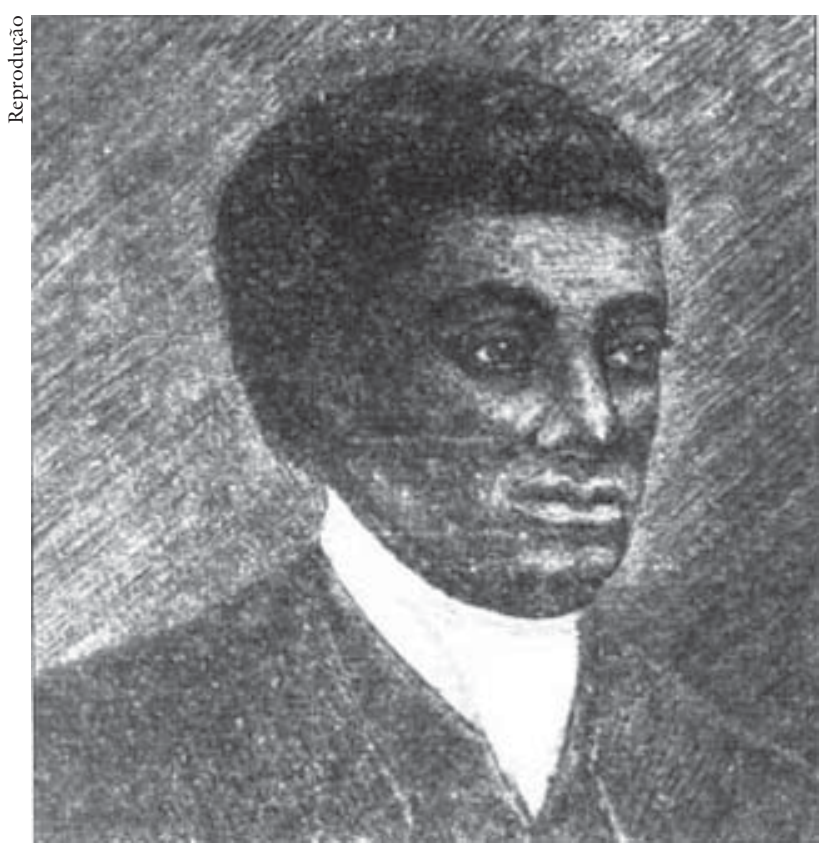

Benjamin Banneker (1731-1806) contestou as afirmações preconceituosas de Jefferson sobre a inferioridade intelectual do negro

Havia, porém, uma área muito significativa em que Jefferson acreditava que os negros eram em tudo iguais aos brancos: eles possuíam um "senso moral". Como sublinha Jordan, para ele negar esse fato teria sido o mesmo que excluir os negros da participação da espécie humana. Era essa faculdade que, na crença do virginiano, separava o homem dos animais. Embora possa ter duvidado de que todos os homens fossem criados iguais, ele não negou que os negros fossem homens (36). É curioso que Jefferson, que não conseguiu identificar o meio ambiente como responsável pelas diferenças observadas nas habilidades intelectuais das raças, recorreu a essa interpretação para explicar as falhas dos negros com relação aos padrões de moralidade dos brancos.

Defendia os negros da acusação de serem por natureza inclinados a roubar e atribuía esse traço à sua condição mais do que a "alguma depravação do senso moral”. E acrescentava: “o homem em cujo benefício não existem leis de propriedade provavelmente se sente menos obrigado a respeitar as leis feitas em benefício de outros. Quando argumentamos em nossa defesa, tomamos como fato básico que as leis, para serem justas, devem conter uma retribuição de direito; que, sem isso, são meras regras arbitrárias de conduta, fundadas na força e não na consciência. E aqui está um problema que deixo para o senhor de escravos resolver: os preceitos religiosos contra a violação da propriedade não foram feitos para ele assim como para o seu escravo?" (37). 
Thomas Jefferson (1743-1826), principal redator da Declaração

da Independência, recusou-se

a libertar seus escravos

e manteve em testamento

a sua propriedade

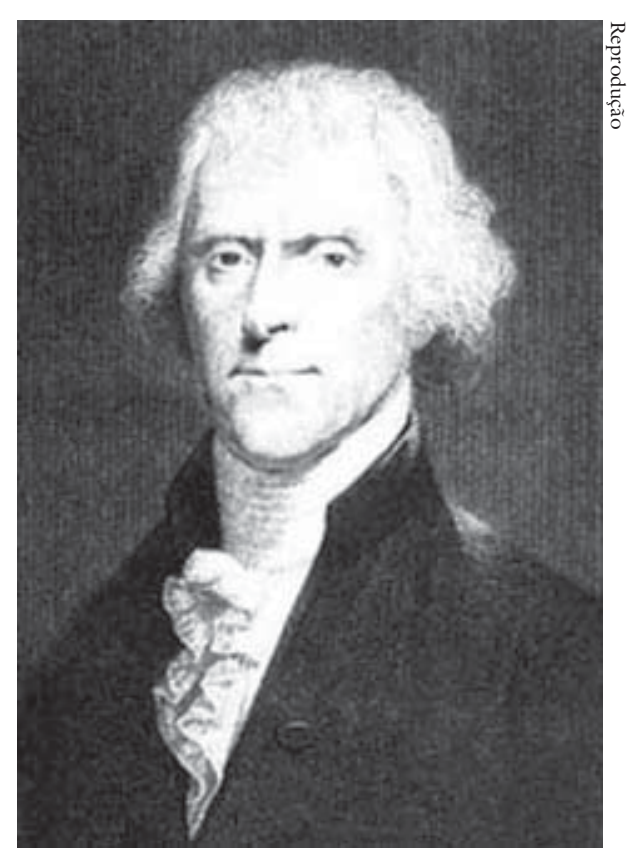

Jefferson sublinhava em seguida que havia encontrado numerosos exemplos de rígida integridade entre os negros e que a benevolência, gratidão e fidelidade eram vistas com a mesma freqüência em escravos e em senhores (38).

Os pontos de vista de Jefferson sobre escravidão e raça sugerem que seus sentimentos libertários foram mais do que contrabalançados pela convicção de que os negros eram membros de uma raça tão diferente e inferior que não se podia esperar que brancos e negros pudessem conviver lado a lado em pé de igualdade. Seus pontos de vista libertários, todavia, não tiveram impacto algum sobre suas ações depois de 1784, e a crença na inferioridade dos escravos estava em perfeita sintonia com seu comportamento como senhor de plantation e político.

Em seu dia-a-dia o comportamento de Jefferson como proprietário de homens pouco se diferenciava daquele dos senhores de plantations da Virgínia que se opunham a suas especulações antiescravistas. Seus cativos alimentavam-se e vestiam-se bem e tinham uma carga de trabalho comparável à de libertos brancos (39). Desse ponto de vista a sorte deles talvez tenha sido mais suave do que a de muitos outros escravos no estado. Apesar de tudo, quando se tratava de fugitivos, vendas de escravos, procriação, castigos físicos e alforrias, o comportamento de Jefferson não diferia sensivelmente daquele de outros senhores de escravos esclarecidos que lamentavam a crueldade sem motivo mas que empregariam quaisquer meios que achassem necessários para proteger sua forma peculiar de propriedade. 
Durante a vida adulta de Jefferson mais de 40 de seus negros tentaram fugir (40); 30 foram mencionados numa de suas cartas ao doutor William Gordon, um inglês que lutara do lado norte-americano na Revolução e voltara para a Grã-Bretanha em 1786. Jefferson descreveu as depredações de lorde Cornwallis com suas tropas quanto atravessaram sua propriedade em 1781 e acrescentou: "também foram levados uns 30 escravos; tivesse sido para dar-lhes a liberdade, lorde Cornwallis teria feito a coisa certa, mas foi para entregá-los à morte inevitável pela varíola e pelo tifo que grassavam em seu exército" (41).

O relatório citado difere muito das frias anotações registradas em seu Farm book quando tais fatos ocorreram. Nesse registro, que não se destinava aos olhos do público, ele fez a listagem dos nomes dos escravos que havia perdido e descreveu a sorte que lhes coubera. Ao lado de um grupo de oito nomes escreveu: "debandaram para o inimigo e morreram". De outros dois escravos disse que haviam "aderido ao inimigo e morrido"; enquanto outros quatro "aderiram ao inimigo, voltaram e morreram". Ao lado de três nomes, um comentário lacônico: "aderiram ao inimigo", e presume-se que tenham conseguido sobreviver à guerra. Um escravo, Barnaby, foi descrito como tendo "fugido, voltado e morrido". De quatro escravos escreveu que "aderiram ao inimigo, mas voltaram novamente e viveram" (42). Em nenhum ponto do relatório aparece a expressão "foram levados", e seu emprego mais tarde suaviza o fato de que mais de um sétimo dos negros de Jefferson escolheram desertá-lo.

A declaração de Jefferson de que Cornwallis teria feito a coisa certa se tivesse levado os negros para dar-lhes a liberdade não condiz com o comportamento do virginiano antes e depois de 1781. Em 1769 publicou um anúncio no Virginia Gazette pedindo o retorno de uma escrava fugitiva chamada Sandy (43). Ao longo da vida Jefferson contratou apanhadores de escravos e quando algum fugia em busca da liberdade pedia aos amigos que ficassem de olhos bem abertos para detectá-lo. No início de setembro de 1805, James Hubbard, um negro robusto que trabalhava na fábrica de pregos da plantation, fugiu, mas logo foi apanhado e devolvido. Cerca de cinco anos mais tarde, fugiu outra vez. Um ano se passou antes que Jefferson soubesse que Hubbard estava morando na região de Lexington e para lá despachou Isham Chisolm para recuperar o cativo. Mas já era tarde. Hubbard partira alguns dias antes para destino desconhecido. Quando Chisolm retornou de mãos vazias, Jefferson lhe ofereceu um bônus de US\$ 25 para que empreendesse uma segunda busca. Desta vez Hubbard foi apanhado e trazido de volta, posto a ferros e Jefferson relatou: "Mandei açoitá-lo com severidade na presença de seus companheiros". Acrescentou em seguida 
sua convicção de que Hubbard "nunca mais servirá a alguém como escravo. $\mathrm{Na}$ hora em que sair da cadeia e seus ferros sumirem ele próprio sumirá". Antes que Jefferson conseguisse realizar seu plano de vendê-lo, Hubbard desapareceu mais uma vez (44).

Em tese, Jefferson não acreditava que um homem tivesse o direito de ser proprietário de outro e, portanto, nenhum homem tinha o direito de vender outro. Repetidas vezes expressou sua aversão por esse comércio e tentou evitar vender sua propriedade humana exceto por mau comportamento ou a pedido dos próprios envolvidos (45).

Todavia, quando ficava descapitalizado e precisava de dinheiro vivo, ocorria a venda de escravos independentemente de seus desejos no caso. Em 1787, estando muito endividado como conseqüência de obrigações que herdara de seu sogro, Jefferson escreveu ao administrador de sua plantation: "O tormento mental que sou obrigado a sofrer até a hora em que não deva um único centavo a ninguém é tão grande que faz minha vida ter pouco valor. Não consigo decidir-me a vender minhas terras. Já vendi uma parte demasiado grande, e elas são a única provisão segura para meus filhos. Nem tampouco venderia meus escravos enquanto houver alguma perspectiva de pagar minhas dívidas com o trabalho deles. Neste ponto oriento-me somente considerando sua felicidade que faz que para eles valha a pena fazer sacrifícios extraordinários durante algum tempo para que eu possa no fim dar-lhes uma condição melhor, o que farei tão logo houver saldado as dívidas sobre a propriedade, dois terços das quais foram contraídos na compra deles" (46).

Essas observações parecem corroborar a idéia de que a primeira preocupação de Jefferson era o bem-estar de seus cativos, mas a verdade é justamente o contrário. A suposição por trás dessa carta é de que os escravos lhe devem uma subsistência e que, se não a fornecerem, serão eles que deverão sofrer. Uma segunda implicação é a de que ele tem o direito de dispor deles como achar melhor. Agindo baseado neste modo de ver as coisas nos anos de 1783-1794, relutando, vendeu cerca de 50 de seus escravos (47).

Quando vendia escravos, Jefferson fazia o possível para manter as famílias unidas se isso não implicasse para ele sacrifício financeiro algum. Em 1792, vendeu dois homens chamados York e Jame e ofereceu incluir no negócio seus pais já idosos, Judy e Will, caso estes quisessem acompanhar os filhos. Seu gesto talvez lhe poupasse dinheiro tirando-lhe das costas o peso de cuidar do casal de velhos que já não serviam para grandes trabalhos. Jefferson não permitia que escrúpulos por dividir famílias interferissem em seus negócios, como fica demostrado pelo fato de, no mesmo lote de escra- 
vos com Jame e York, estar Dilcey, mulher de 21 anos, cujos preciosos pais permaneceram na propriedade dele (48).

Os 11 escravos do sexo masculino a serem vendidos nesse lote eram insuficientes para a realização de um leilão apenas com eles, motivo pelo qual Jefferson orientou seus representantes a levá-los "para algum outro leilão regional onde fossem vendidos". Tinha ele um outro motivo para vendê-los em outro lugar: "Não gosto (enquanto estou na vida pública) de ter meu nome nos documentos oficiais de leilões de propriedade" (49). Não está claro se ele estava se referindo especificamente à propriedade de escravos ou à propriedade em geral.

Quando a medida não lhe trazia sérios prejuízos, Jefferson procurava juntar marido e mulher e se dispunha a comprar ou vender um parceiro do casal para permitir que os dois vivessem juntos. Descrevia-se como alguém "sempre disposto a favorecer as uniões sérias daquela gente, quando se pudesse fazê-lo de modo razoável” (50). Em 1792, ao precisar vender mais alguns escravos para saldar dívidas, propôs vender uma escrava e seus filhos ao seu irmão que era dono do marido dela. A cativa vinha há algum tempo pedindo para juntar-se ao marido, mas seus desejos tiveram de aguardar até que tal procedimento fosse conveniente para Jefferson (51).

Em novembro de 1806, Jefferson anotou que sempre tivera a intenção de comprar a mulher de seu escravo Moses, quando pudesse "dispor do dinheiro", mas na ocasião não podia. Disse que estava disposto a contratála, mas temia que não tivesse sido criada para trabalhar no campo. Todavia, informou seu administrador que tinha permissão para empregá-la se ela conseguisse ganhar para manter-se. Ela não foi contratada, e Moses e sua mulher ficaram separados pelos seis meses seguintes. Mas ao cabo desse período Jefferson de fato comprou a mulher e seus filhos (52).

Pode-se argumentar que, embora Jefferson deplorasse a instituição da escravatura e sobretudo a compra e venda de homens, as compras e vendas que fez foram inevitáveis, uma vez que foram efetuadas para pagar dívidas ou reunir famílias. Mas em 1805, ele disse que estava "tentando comprar homens negros jovens e fortes" para a sua plantation (53). Não há dúvida então de que ele não estava simplesmente envolvido numa operação de investimento de capital no intuito de proteger seus escravos de um mundo cruel e inóspito.

Como outro empresário qualquer, Jefferson se preocupava com o problema de aumentar seus bens de capital - terras e negros. Pelo fato de sempre precisar de dinheiro vivo, era-lhe difícil aumentar seus investimen- 
tos em terras, e nunca o fez. Os escravos, porém, aumentavam naturalmente, e Jefferson se esforçou para garantir que sua fonte de lucros não se perdesse por falta de visão.

Em 1819 instruía seu administrador nos seguintes termos: "Não tenho nenhum motivo para acreditar que algum feitor, desde a época de Griffin, os tenha sobrecarregado com trabalho. Assim, os óbitos entre os adultos parecem atribuíveis a causas naturais, mas a perda de cinco criancinhas em quatro anos me leva a temer que os feitores não permitem que as mulheres dediquem o tempo necessário ao cuidado de seus filhos: que eles vêem a mão-de-obra delas como o primeiro objetivo e a criação dos filhos apenas como algo secundário. Eu não considero a mão-de-obra de uma mulher procriadora como um objetivo, e vejo que um filho criado a cada dois anos dá mais lucro do que a produção agrícola do homem considerado o melhor trabalhador. Neste ponto, como em outros, a providência fez nossos interesses e deveres coincidir perfeitamente. ... Peço-lhe que ponha na cabeça dos feitores que não é a mão-de-obra delas que nos interessa em primeiro lugar, mas sim sua multiplicação (54).

Entre 1810 e 1822 , cerca de 100 escravos nasceram das "mulheres procriadoras" de Jefferson, enquanto apenas 30 dentre seus negros morreram ou foram vendidos ou fugiram (55).

Em toda a sua vida, parece que Jefferson emancipou apenas dois escravos. E um deles comprou a liberdade em 1792 pelo preço de 60 libras. Antes de sua morte, em 1826, Jefferson alforriou mais cinco negros e deixou em testamento 260 cativos para seus herdeiros. Dos sete escravos que libertou, pelo menos cinco eram membros de uma família de mulatos denominada Hemings, e parece bem comprovado que esses indivíduos favorecidos descendiam diretamente de seu sogro. Apesar disso, vários deles continuaram escravos depois da morte de Jefferson. Em 1822, duas garotas Hemings, cansadas de aguardar a liberdade, fugiram para Washington (56).

Parece que a indisposição de Jefferson de alforriar seus escravos deveu-se, pelo menos em parte, à relutância em alterar seu padrão de vida e em harmonizar a prática com seus princípios. Orgulhava-se muito de seus vinhos finos, bons livros e da generosa hospitalidade que se encontrava em Monticello. E esforçava-se muito para manter intacta tal herança para a posteridade (57). Pode-se argumentar que ele não acreditava na emancipação a não ser que viesse acompanhada de uma colonização, o que é bastante verdadeiro. Mas se esse tivesse sido o único obstáculo à emancipação de seus escravos, ele poderia ter tomado medidas para a expatriação dos que escolhessem a liberdade. 


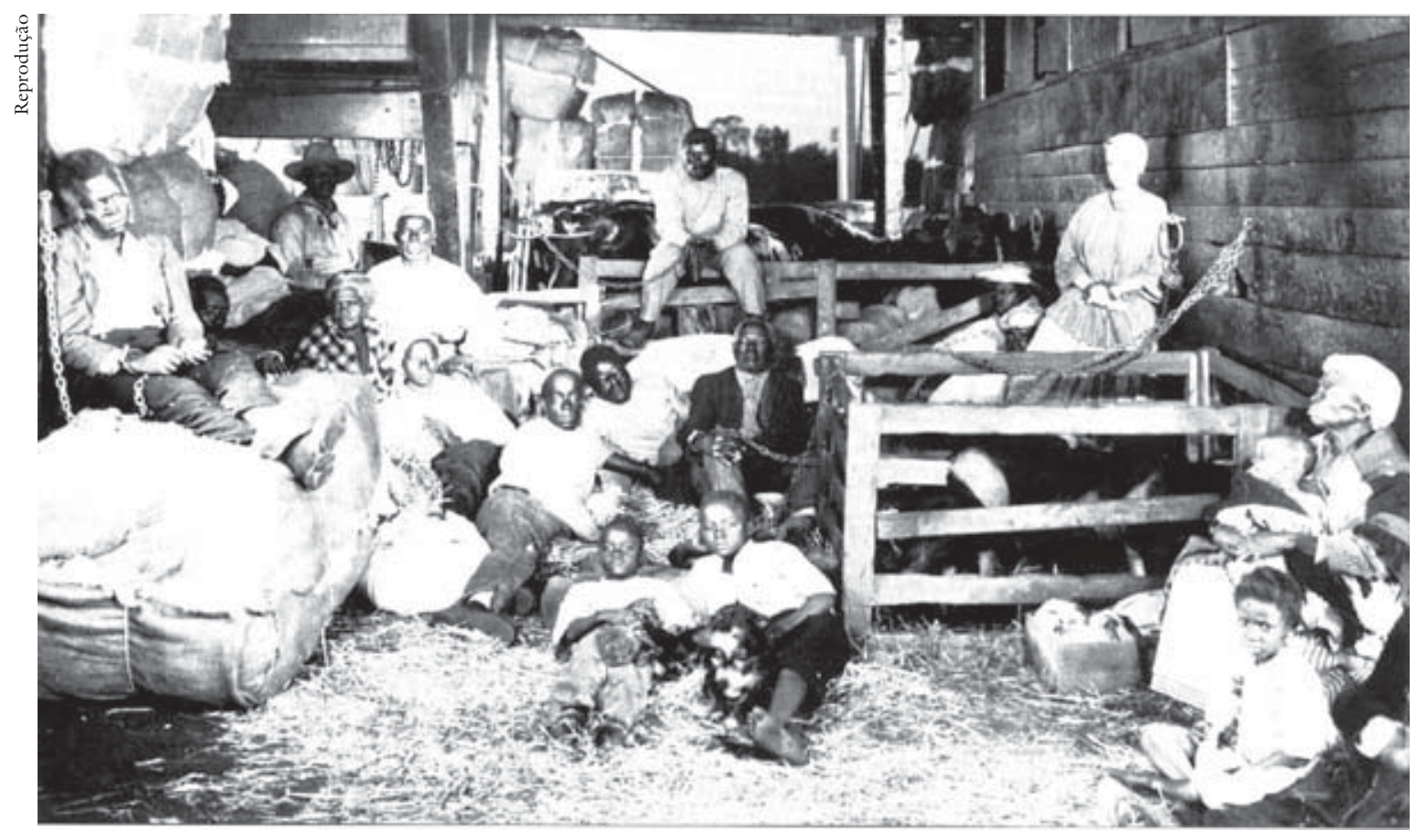

Cena da versão cinematográfica de Uncle Tom's Cabin, 1927

Apesar de as alforrias serem raras na Virgínia nessa época, não eram de forma alguma inauditas. Antes de George Washington morrer, em 1799, deu liberdade a seus escravos, e o mesmo fez o conselheiro de Jefferson, George Wythe, falecido em 1806. Coles, um jovem senhor de plantation, que fora secretário do presidente James Madison, foi ainda mais longe: em 1819 migrou para Illinois com seus escravos e deu a cada família deles 160 acres de terra juntamente com a liberdade. Quando o excêntrico John Randolph de Roanoke morreu em 1833 (sete anos depois de Jefferson), seu testamento continha uma cláusula para a emancipação de seus 400 cativos (58).

Se o interesse pessoal desempenhou um papel preponderante na determinação do comportamento de Jefferson como senhor de plantation, o mesmo interesse foi igualmente importante na determinação de sua atitude como líder nacional em questões envolvendo a escravidão. Depois de 1784 ele evitava discutir o problema em público por razões políticas, mas a questão veio à tona em algumas ocasiões no desempenho de deveres oficiais. Como embaixador na França, esmerou-se para justificar a reivindicação americana de compensação por escravos tomados pelos ingleses em 1783. E continuou pedindo satisfação sobre essa questão ao exercer a função de secretário de Estado, quando pressionou o governo espanhol a negar direito de asilo a escravos fugitivos da Georgia (59). 
Embora Jefferson abraçasse a Revolução Francesa, tremeu de medo em agosto de 1791 quando os escravos da ilha de Santo Domingo se rebelaram pela liberdade; aprovou um fornecimento de armas e munição destinado aos seus senhores que se preparavam para a batalha. A situação complicou-se quando ficou evidente que um segundo fornecimento, ainda maior, poderia provocar o ressentimento da pátria-mãe francesa. E Jefferson insistiu para que futuros pedidos de ajuda fossem encaminhados por intermédio de Paris. Contudo, continuou a simpatizar com a aristocracia da ilha e, quando em 1793 muitos aristocratas fugiram para os Estados Unidos, argumentou que deveriam ser socorridos com generosidade. Fiel às suas convicções sobre os direitos dos estados, negou ao governo federal o poder de empregar dinheiro para tal propósito, mas negou-o "com o coração sangrando". Implorou a James Monroe para que convencesse o governo da Virgínia a fazer um grande donativo aos refugiados justificando: "nunca se apresentou uma tragédia tão dura aos sentimentos dos homens" (60).

A rebelião de Santo Domingo tocou um ponto sensível de Jefferson, pois ele temia que no fim a Virgínia conhecesse o mesmo tipo de violência assassina. Advertiu Monroe de que já era tempo "de prever as cenas sangrentas que nossos filhos com certeza, e talvez nós mesmos ... teremos de atravessar, e tentar evitá-las”. Quatro anos depois, em 1797, novamente insistia que "se não se fizer alguma coisa, e logo, seremos assassinos de nossos próprios filhos” (61).

Três anos mais tarde, seus piores temores pareciam prestes a se concretizar quando uma revolta de escravos na Virgínia, que pode ter envolvido mil negros, foi abortada. Monroe informou a Jefferson que dez dos rebeldes já tinham sido enforcados e perguntava o que fazer com os conspiradores restantes. Jefferson, desaconselhando outras execuções, advertia: "outros estados e o mundo todo nos condenarão para sempre se alimentarmos um princípio de vingança, ou se avançarmos um passo além do absolutamente necessário. Eles não podem deixar de ver os direitos dos dois lados e o objetivo do lado perdedor". O conselho era bom, mas não impediu a execução de aproximadamente 25 negros envolvidos na trama (62).

Dentro de alguns meses Jefferson tornou-se presidente, mas não fez uso de seu cargo para evitar as cenas sangrentas que havia previsto. Profundamente preocupado com a revolta de escravos de 1800, o poder legislativo da Virgínia pediu ao governador Monroe que consultasse o presidente sobre meios de deportação de negros que poderiam se envolver em futuras insurreições. Jefferson, há muito tempo um defensor da colonização de escravos libertos, pediu então ao embaixador norte-americano na Inglater- 
ra para que negociasse com a Companhia Sierra Leone a "recepção daquela gente que lá pudesse ser colonizada". Depois de saber que a Companhia não estava querendo considerar a proposta, o presidente abandonou seus esforços de colonização enquanto durou seu mandato (63).

Os atos de Jefferson a favor da escravidão tornaram-se particulamente evidentes na área da política externa, e o tratado que cedeu o território da Louisiana aos Estados Unidos continha uma cláusula que protegia o direito dos espanhóis e franceses daquela região de manter seus escravos. A insistência francesa nessa condição era compreensível, assim como sua aceitação pelos Estados Unidos. Mas o autor do Regulamento de 1784 não tomou medida alguma para limitar a introdução de outros escravos na região (64).

Napoleão desistira da Louisiana em grande parte por sua incapacidade de esmagar as forças rebeldes de Santo Domingo. Por volta de 1806 novamente alimentou a esperança de reconquistar a ilha e pediu que o governo norte-americano cooperasse interrompendo todo o comércio com a nação negra. Jefferson concordou com esse pedido e recomendou a medida ao Congresso, onde foi aprovada na Câmara numa votação de 93 a 26 . O presidente apoiou a França nessa aventura porque esperava que Napoleão retribuísse ajudando os Estados Unidos a adquirir a Flórida, mas ele com certeza sabia que se o plano obtivesse êxito destruiria o regime negro da ilha, regime que era um farol de esperança para os escravos norte-america$\operatorname{nos}(65)$.

Apesar de tais ações, a marca dominante da administração de Jefferson na questão da escravidão foi seu discreto silêncio. Quando cidadãos de território da Indiana estavam exigindo que a escravidão fosse permitida em toda a região do Noroeste, o presidente não fez qualquer comentário (66). Embora na intimidade continuasse a se apresentar como um inimigo do cativeiro humano e em algumas raras ocasiões durante a presidência expressasse tais sentimentos em cartas a destinatários que compartilhavam seu ponto de vista, tinha um cuidado extremo para evitar que esses pensamentos viessem a público.

Quando recebeu um tratado sobre a emancipação de Thomas Brannagan, um traficante de escravos convertido em abolicionista, Jefferson não respondeu diretamente ao pedido de endosso do autor. Em vez disso, escreveu ao Dr. George Logan: "A causa que ele abraça é tão sagrada, os sentimentos que expressa em sua carta são tão amáveis que é muito penoso para mim hesitar numa anuência que parece tão pequena. Mas essa não é sua verdadeira natureza, e seria uma injúria até para seus pontos de vista eu me comprometer por escrito respondendo a sua carta. Tenho tido todo o 
cuidado em evitar qualquer ação ou manifestação pública sobre esse assunto. Caso se apresente uma ocasião em que eu possa interferir de forma decisiva, certamente saberei qual será meu dever e o cumprirei com prontidão e zelo" (67).

De fato, quando escrevia essas palavras, Jefferson já havia desistido de "uma expectativa de qualquer medida precoce para a extinção da escravidão entre nós”, e suas ações parecem ter sido concebidas mais para calar a discussão da questão do que para resolvê-la (68).

Dez anos após deixar a presidência, quando a questão do Missouri dividia a nação, Jefferson ainda demostrava sua habilidade em misturar vagos sentimentos abolicionistas com uma posição que funcionava em benefício dos estados escravistas. Reconhecendo que a disputa sobre a admissão do Missouri anunciava uma era de crescente divisão nacional acerca da questão da escravatura, comparou a controvérsia a um "alarme de incêndio dentro da noite" e advertia contra o desastre iminente para a União. Falando da escravidão, implicitamente endossava a posição moral do Norte quando descrevia os problemas do Sul: "Pegamos o lobo pelas orelhas e não podemos segurá-lo nem, sem risco, deixá-lo escapar. A justiça está num dos pratos da balança e a autopreservação no outro". E mencionava a disposição de liberar seus cativos se fosse possível encontrar algum modo viável de emancipá-los e expatriá-los (69).

Apesar de tudo, endossou a posição do Sul e acusou os federalistas de criar uma divisão geográfica baseada numa questão nitidamente moral com o intuito de retomar a sua influência. Negava depois que a moralidade estivesse envolvida, uma vez que a limitação da área da escravidão não libertaria ninguém. Negava também que o governo federal pudesse regular a "condição de tipos diferentes de homens que compunham o estado”, e excluía o único meio prático com o qual finalmente se poderia provocar a emancipação (70).

Pode-se argumentar que a posição de Jefferson na questão do Missouri, e também sua falta de iniciativa como presidente, talvez tenha sido imposta por sua estrita construção da constituição. Quando, porém, o objetivo era bastante amplo, Jefferson sabia ser muito flexível. Ele não permitiu que tais escrúpulos impedissem a aquisição do território da Louisiana. Além disso, acreditava que a expatriação dos negros da América era um tema que merecia igual elasticidade.

Apesar de seu apoio à posição sulista na questão do Missouri, em 1821 Jeferson ainda escrevia: "Não há nada mais certo gravado no livro do destino do que o fato de que estes povos serão livres. Nem é menos certo 
que estas duas raças, igualmente livres, não podem conviver no âmbito do mesmo governo" (71). Assim, nos últimos anos de vida continuava insistindo que a emancipação deveria ser acompanhada da expatriação. Todavia, não se entusiasmava com o plano de reconduzir os negros para a África e acreditava que a distância daquele continente impossibilitaria a realização de tal operação $(72)$.

Em 1824 Jefferson argumentava que havia um milhão e meio de escravos na nação e que ninguém imaginava que fosse "viável para nós, ou vantajoso para eles”, mandar embora todos os negros imediatamente.

Em seguida calculava: "Seu valor como propriedade, em primeiro lugar (uma vez que houve um investimento legal de propriedade real em sua aquisição, e quem pode tirar legalmente essa propriedade de seus detentores?), a uma média de duzentos dólares a unidade ... totalizaria seiscentos milhões de dólares que alguém teria de receber ou perder. Acrescente-se a isso o custo de transporte por terra e por mar até Mesurado, um ano de provisões de comida e vestuário, implementos agrícolas para suas profissões, o que totaliza mais trezentos milhões ... e torna-se impossível voltar a discutir a questão" (73).

Uma vez que a colonização na África parecia impossível, Jefferson sugeriu um plano que implicava "emancipar os nascidos após sua aprovação, deixando-os, com a devida compensação, na companhia das mães até que seus serviços pagassem seu sustento, e mantendo-os em ocupações sérias até que atingissem a idade apropriada para a deportação" (74). Os indivíduos que fossem "libertados" imediatamente após o nascimento seriam depois enviados para Santo Domingo que, segundo os jornais, ultimamente se propusera abrir as portas para essa gente. De fato, Jefferson estava propondo que o governo federal comprasse de seus donos todos os escravos recém-nascidos (ao preço de US\$ 12,50 por indivíduo) e que pagasse por sua "alimentação e de sua mãe por alguns anos". Além disso, o plano nada custaria ao governo, pois os jovens negros passariam a trabalhar para sustentar-se até a deportação. Santo Domingo se predispusera a assumir o custo da passagem.

Jefferson notou que a maioria dos americanos daquela época viveriam o bastante para ver a população atingir a casa dos seis milhões e alertava que "um milhão e meio estão sob controle; mas seis milhões, ... e um milhão desses combatentes dirão: 'nós não iremos' ".

O estadista virginiano concluía sua proposta insistindo que não se deveria permitir que nem problemas constitucionais nem sentimentos humanos impedissem sua execução: 


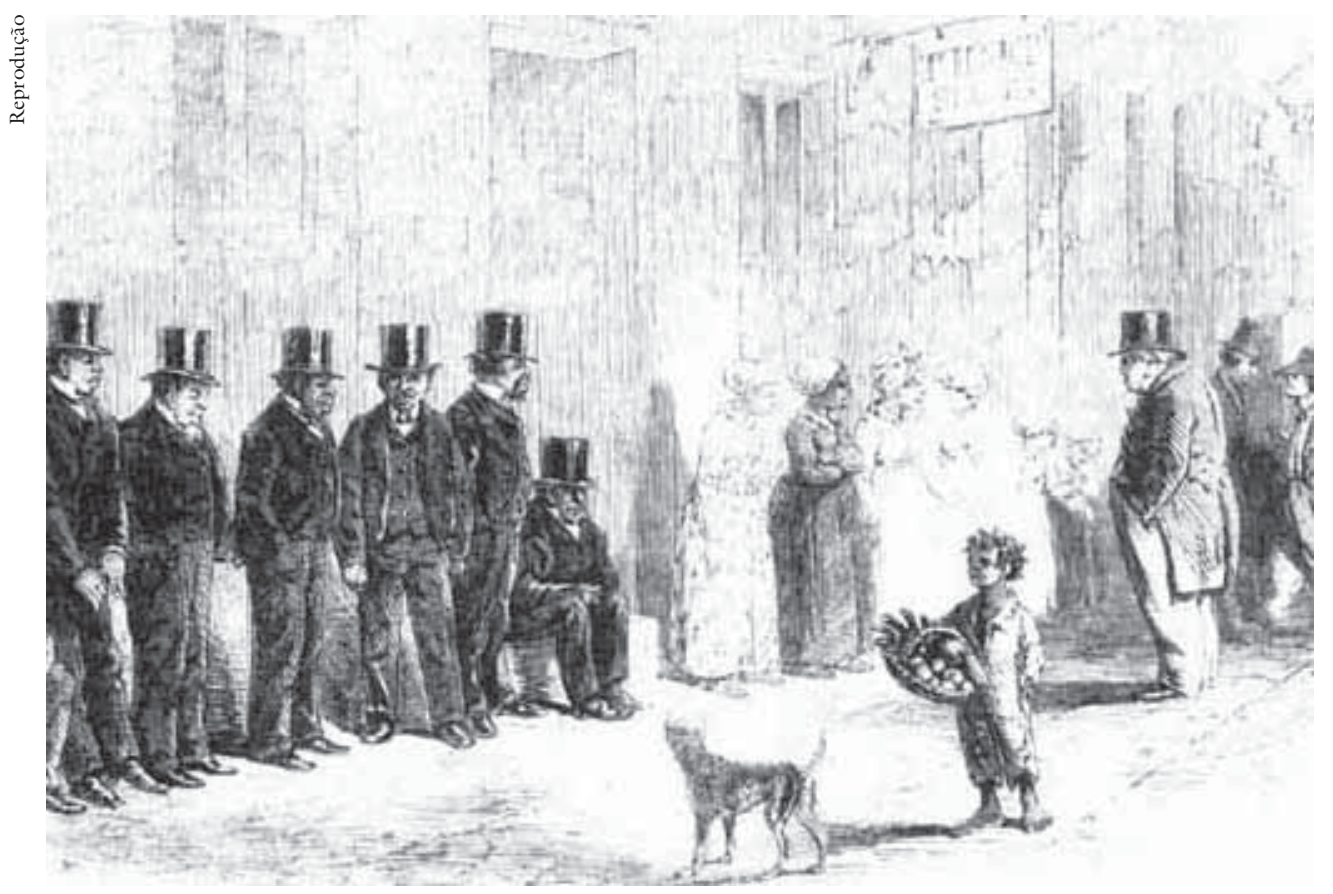

Ilustração retratando compra de escravos no Sul dos Estados Unidos

"Tenho consciência de que este assunto envolve alguns escrúpulos constitucionais. Mas uma constituição liberal, justificada por seu objetivo, pode ir longe, e uma emenda constitucional pode chegar até onde for necessário. Também a separação de crianças de suas mães seria motivo de alguns escrúpulos. Mas isso seria coar um mosquito e engolir um camelo"(75).

Assim, apenas dois anos e meio antes de sua morte, Jefferson reiterou a velha crença de que a emancipação era imperativa para o bem da nação, mas deveria vir acompanhada da colonização. Mesmo neste ponto, porém, sua teoria diferia de sua prática. E neste caso a incoerência o acompanharia para além do túmulo uma vez que não se dispôs a libertar seus escravos sob condição de que deixassem o país. Pelo contrário, pediu em seu testamento que a legislatura da Virgínia concedesse uma licença especial aos cinco escravos alforriados por ele para permanecer no estado (76).

Jefferson foi um homem de muitas dimensões, e a explicação de seu comportamento contém logicamente inúmeras aparentes contradições. Era um sincero e dedicado inimigo do tráfico de escravos, mas comprou e vendeu homens sempre que achou necessário para o seu caso pessoal. Acreditava que todos os seres humanos tinham direito à vida e à liberdade independentemente de sua capacidade e, contudo, saiu no encalço dos escravos que ousaram assumir esses direitos empreendendo fuga. Acreditava que a escra- 
vidão fosse um erro do ponto vista moral e político, mas assim mesmo escreveu um código para os escravos de sua propriedade e em 1819 foi contra uma tentativa de limitar a expansão da instituição. Acreditava que uma hora de escravidão era pior do que séculos de opressão inglesa, mas era capaz de discutir a questão da procriação de escravos praticamente nos mesmos detalhes que consideraria se estivesse falando da propagação de cães ou cavalos.

De um ponto de vista intelectual, é provável que sua forte "suspeita" de que os negros eram por natureza inferiores teve grande importância na explicação de sua capacidade de ignorar as próprias restrições a seus direitos. Pensando neles como homens inferiores, poderia convencer-se de que seu comportamento com eles era benevolente e humanitário. E de fato era, julgado à luz das convicções tradicionais dos senhores de escravos. Mas é um erro tratar o relacionamento de Jefferson com seus escravos em termos intelectuais e psicológicos, uma vez que a instituição formava a urdidura e a trama da vida em Monticello e suas especulações abstratas sobre a liberdade humana pouco pesavam quando comparadas com o esquema completo de sua existência nesse contexto.

Interagindo como causa e efeito na determinação do comportamento antiescravista de Jefferson havia todo um conjunto de fatores que incluíam a crença na inferioridade dos negros, $\mathrm{o}$ ambiente da sociedade que aceitava sem questionar a escravização de uma raça por outra e o fato de ser ele proprietário de 10 mil acres de terra e de mais de 200 escravos (77). Sua riqueza, statuse posição política estavam ligados ao sistema da escravidão, e nem sequer uma vez propôs ativamente um plano que teria posto em risco tudo o que possuia. Na maioria das vezes, seus atos com relação a escravatura, na verdade, reforçaram a instituição. É o que se observa em sua autoria do código para os escravos da Virgínia de 1778, em seu apoio aos senhores de plantations de Santo Domingo e em sua posição na questão do Missouri.

Monticello foi a oficina do criador do "sonho agrário". Foi lá que Jefferson fez suas experiências agrícolas e científicas e ofereceu generosa hospitalidade a seus visitantes. Foi lá que viveu uma vida agitada mas agradável, longe dos cambistas urbanos do Norte. Era a vida que ele procurava preservar contra as incursões das forças do comércio e da indústria. Mas não se deve esquecer que o mundo de Jefferson dependia da mão-de-obra escrava para poder existir. 
Notas

1 Thomas Jefferson a Edward Everett, 8 de abril de 1826, Paul Leicester Ford (ed.), The works of Thomas Jefferson, 12 v., New York, 1904-1905, XII, p. 469. Thomas Jefferson a Richard Price, 7 de agosto de 1785; Thomas Jefferson a Jean Nicholas Demeunier, 26 de junho de 1786, Julian P. Boyd (ed.), and Lyman H. Butterfiedl \& Mina R. Bryan (associate ed.), The papers of Thomas Jefferson, 17 v., Princeton, 1950-1965, VIII, p. 357, X, p. 63.

2 Dumas Malone, Jefferson and his time, 3 v., Boston, 1948-1962, III, p. 212. Dumas Malone é o mais proeminente defensor da tese segundo a qual, embora T. Jefferson não gostasse de seu papel de proprietário de escravos, esta situação foi uma herança que lhe coube. Henry S. Randall tem um parecer semelhante. Escritor novaiorquino, autorizado pela família a escrever sobre Jefferson, Randall tratou a questão da escravidão com cautela; e o quadro que emerge da vida na plantation é extremamente idílico. Henry S. Randall, The life of Thomas Jefferson, 3 v., New York, 1958, p. 152-153, III, p. 667-669.

Marie Kimball, Jefferson: the road to glory, 1743-1776, NewYork, 1943, e Gilbert hinard, Thomas Jefferson: the apostle of Americanism, $2^{2}$ ed. revista, Ann Arbor, 1957, descrevem ambos suas opiniões antiescravistas em termos candentes, mas não atacan a contradição entre essas idéias e seu papel de proprietário de plantation. O mesmo vale para Adrienne Kock, Jefferson and Madison: the great collaboration, New York, 1950. Depois de descrever o plano de emancipação de Jefferson de 1778, ela descarta sua incoerência.; "pode-se especular sobre as conseqüências para a história americana, caso a legislação esclarecidda do Jefferson liberal tivesse sido adotada, mas aqui nos abstemos de tal especulação ressalvando que a intenção de Jefferson deve ser observada por todos os que se lembram dele com um "senhor de plantation da Virgínia, proprietário de escravos." Kock, Jefferson and Madison, p. 13.

Natham Schachner, Thomas Jefferson: a biography, New York, 1951, dedica pouco espaço ao problema de Jefferson e a escravidão. Quando trata do assunto, é neutro ou um tanto crítico. Ao escrever sobre o plano de Jefferson de colonizar negros livres e criminosos escravos, ele observa que o senhor de plantation "nada via de errado no fato de se arrancarem sumariamente negros livres de suas casas". Schachner, Thomas Jefferson, p. 704.

Albert Jay Nock, Jefferson, Washington, D. C., 1926, é sob muitos aspectos um retrato sensível e sensato do virginiano, mas aceita sem muito questionar o papel de Jefferson como proprietário de escravos. Observando o desperdício de crianças negras que trabalhavam na fábrica de pregos de Jefferson, Nock escreveu: "mas que de melhor se poderia fazer com esses rapazes .... Não adiantava educá-los acima de sua condição de escravos; e mesmo que alguém os eliminasse, seu lugar seria preenchido quase de imediato por outros precisamente iguais a eles". Nock, Jefferson, p. 68. 
3 T. Jefferson a Edward Coles, 25 de agosto de 1814, Ford (ed.), Works of Thomas Jefferson, XI, p. 416.

4 Ibid., p. 419.

5 Robert McColley, Slavery and Jeffersonian Virginia, Urbana, 1964, p. 124.

6 Winthrop D. Jordan, White over black: American attitudes toward the negro, 1550-1812, Chapel Hill, 1968, p. 429, 431.

7 Ibid., p. 453.

8 Malone, Jefferson and his time, I, p. 439-444.

9 Para uma avaliação da riqueza de Thomas Jefferson comparada com outras do condado de Albemarle, ver ibid., p. 441. Os dados sobre escravos provêm de Thomas Jefferson, Farm book, p. 5-9, 24, 57, 128-131. Uma reprodução facsimilar desse documento encontra-se em Edwin Morris Betts (ed.), Thomas Jefferson's Farm book: with relevant commentary and extracts from other writings, Princeton, 1953. Os extratos e o Farm book estão enumerados separadamente e cada um começa pelo número 1 , as referências ao fac-símile serão citada como T. Jefferson, Farm book, e as referências aos extratos como Betts (ed.), Thomas Jefferson's...

10 Thomas Jefferson, A summary view of the rights of British America, Boyd (ed.), Papers of Thomas Jefferson, I, p. 129-130.

11 Ibid., p. 353. Este documento foi escrito antes de 13 de junho de 1776.

12 Carl I. Becker, The Declaration of Independence: a study in the history of political ideas, New York, 1942, p. 212.

13 T. Jefferson, Farm book, p. 7-9; Boyd (ed.), Papers of Thomas Jefferson, I, p. 96.n.

14 T. Jefferson a Henri Gregoire, 25 de fevereiro de 1809, Ford (ed.), Works of Thomas Jefferson XI, p. 100. Ver também Jordan, White over black, p. 429-481; McColley, Slavery and Jeffersonian Virginia, p. 124-132.

15 Em sua autobiografia T. Jefferson asseverou que em 1778 apresentou um projeto de lei para impedir futuras importações de escravos na Virgínia. Paul L. Ford questiona essa reivindicação e observa que Jefferson não fazia parte da legislatura quando o projeto foi debatido e adotado. Ford (ed.), Works of Thomas Jefferson, I, p. 60, 60n-61n. Os editores dos escritos de Jefferson acreditam que ele provavelmente foi responsável pelo projeto e enfatizam que sua ausência não prova necessariamente que tal projeto não resultou de seus esforços. Boyd (ed.), Papers of Thomas Jefferson, II, p. 23n.

16 Randall, Thomas Jefferson, I, p. 58; Ford (ed.), Works of Thomas Jefferson, I, p. 7. 
Em nota de rodapé Ford mostra que uma análise cuidadosa do Journal of the House of Burgesses não revelou qualquer indício de tal esforço. Os editores dos escritos de Jefferson referem-se à sua proposta como "uma extensão da proteção de certas leis aos negros", e enfatizam que a proposta pode ter sido feita "na comissão geral e de alguma outra forma que não exigiu registro". Boyd (ed.), Papers of Thomas Jefferson, II, p. $23 \mathrm{n}$.

17 Essas tentativas foram uma emenda na legislatura da Virgínia de 1778 à lei sobre os escravos; o Regulamento de 1784; a redação de T. Jefferson de uma constituição revisada para a Virgínia. Este último documento estabelecia que todos os escravos do estado seriam libertados depois de 31 de dezembro de 1800. Boyd (ed.), Papers of Thomas Jefferson, VI, p. 298.

18 Essa legislação era a da Lei n. 51 das leis preparadas pela Comissão de Revisores. Ibid., II, p. 470-472. Ford (ed.), Works of Thomas Jefferson, I, p. 77.

19 Boyd (ed.), Papers of Thomas Jefferson, II, p. 471-472, 473n. Em sua versão final aprovada em 1785 , a lei omitiu essas cláusulas.

20 T. Jefferson, Farm book, p. 21-22, 28. Os números para 1776 não aparecem no Farm book e são desconhecidos. T. Jefferson disse que era fato notório que os escravos se multiplicam com a mesma rapidez dos cidadãos livres. Thomas Jefferson, Notes on the state of Virginia, New York, 1964, p. 136. O argumento de que Jefferson acreditava que a escravatura desapareceria aos poucos se a população negra fosse reduzida está em Boyd (ed.), Papers of Thomas Jefferson, II, p. 473n.

21 Jefferson, Notes on ... Virginia, p. 132-133; Boyd (ed.), Papers of Thomas Jefferson, II, p. $472 \mathrm{n}$.

22 Boyd (ed.), Papers of Thomas Jefferson, VI, p. 604.

23 Não está claro qual teria sido o motivo da incorporação imediata no Regulamento da cláusula excludente por T. Jefferson, mas talvez ele a tenha redigido mais com o propósito de deter o tráfico de escravos do que o de enfraquecer a instituição da escravidão. Escrevendo em 1819, James Madison afirmava que a proibição da escravidão que apareceu no Regulamento do Noroeste de 1787 fora adotada como um meio de restringir o tráfico pela redução do mercado potencial de escravos. Ele duvidava que essa medida teria sido proposta se o poder de abolir o tráfico já houvesse sido fixado pelo Congresso. Embora as observações de Madison se referissem claramente ao REgulamento de 1787, parece provável que também se aplicavam à versão anterior. Com os traficantes espanhóis infestando as região do baixo Mississipi, a ameaça dessa área com certeza exigia atenção. Madison a Robert Walsh, 27 de novembro de 1819, Galliard Hunt (ed.), The writings of James Madison: comprising his papers and his private correspondence, including numerous letters and documents now for the 
first time printed, 9 v., New York, 1900-1910, XI, p. 9-10. Ver também McColley, Slavery and Jeffersonian Virginia, p. 171.

24 T. Jefferson a John Holmes, 22 de abril de 1820, Ford (ed.), Works of Thomas Jefferson, XII, p. 159; Boyd (ed.), Papers of Thomas Jefferson, VI, p. 604.

25 McColley, Slavery and Jeffersonian Virginia, p. 125, 178-180; T. Jefferson a Madison, 25 de abril de 1825, Boyd (ed.), Papers of Thomas Jefferson, VII, p. 118-119.

26 Sobre a relutância de T. Jefferson em falar abertamente da escravidão, ver T. Jefferson a [General] Chastellux, 7 de junho de 1785, Boyd (ed.), Papers of Thomas Jefferson, VIII, p. 184; e T. Jefferson a George Logan, 11 de maio de 1805, Ford (ed.), Works of Thomas Jefferson, X, p. 141-142. Sobre sua defesa da expatriação, ver T. Jefferson a Jared Sparks, 4 de fevereiro de 1824, ibid., XII, p. 334-339.

27 Esta análise do pensamento de T. Jefferson sobre a questão da raça foi escrita antes da publicação de White over black. Passou depois por extensa revisão, e esta versão reflete muitos insights que derivam da importante obra de Jordan.

28 T. Jefferson a James Monroe, 17 de junho de 1875, Boyd (ed.), Papers of Thomas Jefferson, VIII, p. 229.

29 Jefferson, Notes on ... Virginia, p. 132-133.

30 Ibid., p. 133-134.

31 Ibid., p. 134-135.

32 T. Jefferson a Joel Barlow, 8 de outubro de 1809, T. Jefferson ao marquês de Condorcet, 30 de agosto de 1791, T. Jefferson a Benjamin Banneker, 30 de agosto de 1791, Ford (ed.), Works of Thomas Jefferson, XI, p. 121, VI, p. 309310,311 .

33 Embora o condicionalismo ambiental tenha conseguido seu espaço em anos recentes, havia muitas pessoas, mesmo na época de Jefferson, que defendiam sua posição; e Jefferson tinha profunda consciência das opiniões dos ambientalistas. T. Jefferson, Notes on ... Virginia, p. 134-138. Abbe Raynal, Adam Smith e Alexander Hamilton estavam entre os que acreditavam que a condição aviltada dos negros se devia exclusivamente aos efeitos de sua situação. John C. Miller, Alexander Hamilton: portrait in paradox, New York, 1959, p. 41-42; David Brion Davis, The problem of slavery in western culture, 1966, p. 420-421, 456.

34 Jefferson, Notes on ... Virginia, p. 137.

35 Ibid., p. 138; Jordan, White over black, p. 438-439.

36 Jordan, White over black, p. 431-432, 439-440. 
37 Jefferson, Notes on ... Virginia, p. 127.

38 Ibid., p. 138.

39 Betts (ed.), Thomas Jefferson's ... writings, p. 5-7.

40 Este dado inclui 30 escravos que passaram para o lado dos ingleses em 1781 e casos que envolveram um ou mais fugitivos mencionados nas seguintes fontes: anúncio sobre uma fugitiva chamada Sandy no Virginia Gazette, 7, 14 de setembro de 1769, George Wythe a T. Jefferson, 31 de dezembro de 1781, Boyd (ed.), Papers of Thomas Jefferson, VI, p. 144; Daniel Bradley a T. Jefferson, 6 de outubro de 1805, T. Jefferson a Joseph Daugherty, 31 de julho de 1806, T. Jefferson a May Dangerfield, 31 de julho de 1808, T. Jefferson a Jeremiah Goodman, 26 de julho de 1813, Joel Yancey a T. Jefferson, 22 de maio de 1821, Betts (ed.), Thomas Jefferson's ... writings, p. 21, 22, 27, 36, 46. Outros dois fugitivos, Beverley e Harriet [Hennings], estão arrolados em Jefferson, Farm book, p. 130. O total de 40 é provavelmente conservador, uma vez que se baseia apenas no estudo das fontes mais disponíveis.

41 T. Jefferson a Villiam Gordon, 16 de julho de 1788, Boyd (ed.), Papers of Thomas Jefferson, XIII, p. 363-364.

42 T. Jefferson, Farm book, p. 29. Albert J. Nock cita a carta de Gordon assim como a anotação no Farm book, mas não explora a contradição entre as duas fontes. Nock, Jefferson, p. 63-64.

43 Virginia Gazette, 7, 14 de setembro de 1769, Boyd (ed.), Papers of Thomas Jefferson, I, p. 33.

44 T. Jefferson a Bradley, 6 de outubro de 1805, T. Jefferson a Reuben Perry, 16 de abril de 1812, 3 de setembro de 1812, Betts (ed.), Thomas Jefferson's ... writings, p. 21, 34-36.

45 T. Jefferson a John W. Eppes, 30 de junho de 1820. T. Jefferson a Craven Peyton, 27 de novembro de 1815, T. Jefferson a Thomas Mann Randolph, 8 de junho de 1803, ibid., p. 45, 40, 19.

46 T. Jefferson a Nicholas Lewis, 29 de julho de 1787, Ford (ed.), Works of Thomas Jefferson, V, p. 311 . Esta carta também se encontra em Boyd (ed.), Papers of Thomas Jefferson, XI, p. 640, mas em vez da palavra exertions [esforços] Boyd emprega a palavra cautions [cautelas].

47 Malone, Jefferson and his time, III, p. 207, I, p. 443-444. Referências a leilões de escravos aparecem em T. Jeffeson a Alexander McCaul, 4 de janeiro de 1787, Boyd (ed.), Papers of Thomas Jeffeson, XI, p. 10; e T. Jefferson a James Lyle, 25 de abril de 1793, Ford (ed.), Works of Thomas Jefferson, VII, p. 278.

48 T. Jefferson a Bowling Clarke, 21 de setembro de 1792, Betts (ed.), Thomas 
Jefferson's ... Virginia, p. 13; T. Jefferson, Farm book", p. 9, 24, 30. Bess era conhecida como Betty em 1774. Em 1795 T. Jefferson escreveu a palavra old ao lado dos nomes de Judy e Will, indicando que já não serviam para trabalhar.

49 T. Jefferson a Clarke, 21 de set. 1792, Betts (ed.), Thomas Jefferson's ... writings, p. 13.

50 T. Jefferson a John Jordan, 21 de dezembro de 1805, ibid., p. 21.

51 T. Jefferson a Randolph Jefferson, 25 de setembro 1792, ibid., p. 14.

52 T. Jefferson a Edmund Bacon, 21 de novembro de 1806, T. Jefferson a Randolph Lewis, 23 de abril de 1807; Livro contábil de 1807, ibid., p. 24-27.

53 T. Jefferson a Jordan, 21 de dezembro de 1805, Betts, ibid., p. 21.

54 T. Jefferson a Yancey, 17 de janeiro de 1819, ibid., p. 43. Em carta a Eppes, em 30 de junho de 1820, T. Jefferson dizia: "Não conheço nenhum erro tão prejudicial a uma propriedade como o de supri-la quase exclusivamente com homens. Considero que uma mulher que tem um filho a cada dois anos dá mais lucro do que o melhor dos homens da fazenda. O que ela produz é uma acréscimo ao capital, ao passo que os resultados do trabalho dele simplesmente desaparecem". Ibid., p. 45-46. A profunda consciência de Jefferson sobre o lucro do crescimento natural dos escravos também aparece em suas observações de que "nossas famílias dobram em 25 anos, o que é um aumento do capital nelas investido $4 \%$ acima da simples manutenção do número original". Ver Jordan, White over black, p. 430.

55 Esses números se baseiam em T. Jefferson, Farm book, p. 130-131.

56 Ibid., p. 130. Para os documentos da libertação de Robert e James Hemings (com datas de 12 de dezembro de 1794 e 5 de fevereiro de 1796, respectivamente), ver Betts (ed.), Thomas Jefferson's ... writings, p. 15. Para o testamento de T. Jefferson, datado de março de 1826, ver Ford (ed.), Works of Thomas Jefferson, XII, p. 482. O relacionamento da família Hemings com Jefferson e seus parentes é discutido em Merrill D. Patterson, The Jefferson image in the American mind, New York, 1960, p. 185-186. Ver também Jordan, White over black, p. 464-468.

57 Em seu testamento, o virginiano esmerou-se em detalhes para fazer que sua propriedade passasse à filha Martha e não aos credores de seu marido. Ford (ed.), Works of Thomas Jefferson, XII, p. 479; McColley, Slavery and Jeffersonian Virginia, p. 23; Randall, Thomas Jefferson, III, p. 332-333; Nock, Jefferson, p. 59.

58 John Alexander Carroll and Mary Wells Ashworth, George Washington: first in peace, New York, 1957, p. 585. "Geoge Wythe”, Dictionary of American biography, 11 v., New York, 1957, XI, p. 588; “John Randolph”, ibid., VIII, p. 366. 
59 Para detalhamento dos tópicos discutidos com Vergennes [ca. 20 de dezembro de 1785], ver Jefferson a John Jay, 23 de abril de 1786, Boyd (ed.), Papers of Thomas Jefferson, IX, p. 111, 403-404; T. Jefferson ao ministro britânico, 29 de maio de 1792, 15 de dezembro de 1793, T. Jefferson ao governador da Flórida, 10 de maio de 1791, T. Jefferson ao governador da Georgia, 26 de março de 1791, Ford (ed.), Works of Thomas Jefferson, VII, p. 41-46, VIII, p. 95-97, VI, p. 212, 226-227.

60 T. Jefferson a Monroe, 14 de julho de 1793, T. Jefferson ao chargé d'affaires na França [William Short], 14 de novembro de 1791, Ford (ed.), Works of Thomas Jefferson, VII, p. 449-450, VI, p. 331-332.

61 T. Jefferson a St. George Tucker, 28 de agosto de 1797, T. Jefferson a Monroe, 14 de julho de 1793, ibid., VIII, p. 334-336, VII, p. 449-450.

62 T. Jefferson a Monroe, 20 de setembro de 1800, ibid., IX, p. 146. Herbert Aptheker, American negro slave revolts, New York, 1943, p. 219-227. O desejo de Jefferson de evitar outras execuções parece ter-se em parte originado de um respeito genuíno pelos rebeldes. Enquanto investigava possibilidades de que esses negros fossem banidos para a África e lá colonizados, observou que "eles não eram criminosos ou malfeitores comuns, mas pessoas culpadas daquilo que a segurança da sociedade, em circunstâncias concretas, nos obriga a tratar como um crime, mas que seus sentimentos podem representar de uma forma muito diferente. São pessoas que serão uma aquisição preciosa para o assentamento já existente [na África] ... e bem talhados para cooperar com o plano da civilização". T. Jefferson a Ruffus King, 13 de julho de 1802, Ford (ed.), Works of Thomas Jefferson, IX, p. 385.

63 Ford (ed.), Works of Thomas Jefferson, IX, p. 383-386. A citação está em T. Jefferson a John Lynch, 21 de janeiro de 1811, ibid., XI, p. 179. A solicitação da legislatura da Virgínia também pedia que fosse analisada a questão de se achar um lugar para onde pudessem ser enviados os negros livres.

64 McColley, Slavery and Jeffersonian Virginia, p. 125.

65 Ibid., p. 112.

66 Ibid., p. 178-180.

67 T. Jefferson a Logan, 11 de maio de 1805, Ford (ed.), Works of Thomas Jefferson, X, p. 141.

68 T. Jefferson a William A. Burwell, 28 de janeiro de 1805, ibid., X, p. 126.

69 T. Jefferson a John Holmes, 22 de abril de 1820, ibid., XII, p. 159.

70 Ibid., T. Jefferson a Albert Gallatin, 26 de dezembro de 1820, ibid., XII, p. 187-189. 
71 Ibid., I, p. 77.

72 T. Jefferson a Jared Sparks, 4 de fevereiro de 1824, ibid., p. 334-335.

73 Ibid., XII, p. 335-336.

74 Ibid., p. 336.

75 Ibid., p. 339.

76 Testamento de T. Jefferson, datado de março de 1826, ibid., p. 483.

77 Esta listagem não pretende excluir o efeito da constituição psicológica de T. Jefferson como fator que influenciou seu comportamento no que se refere à escravidão. Jordan sugere de modo convincente que a crença do virginiano na inferioridade dos negros enraizava-se em parte no mais profundo de sua mente. Ver Jordan, White over black, p. 457-481.

William Cohen é pesquisador associado do Centro de Estudos Urbanos na Universidade de Chicago (EUA).

Tradução de Almiro Pisetta. O original - Thomas Jefferson and the problem of slavery - foi publicado em The Journal of American History, v. LVI, n. 3, p. 503526. 